\title{
Non-Compacted Cardiomyopathy in Children and Adolescents: From the Challenge of Echocardiographic Diagnosis to Clinical Follow-Up
}

\section{Miocardiopatia Não Compactada em Crianças e Adolescentes: do Desafio do Diagnóstico Ecocardiográfico ao Acompanhamento Clínico}

Ana Flávia Malheiros Torbey ${ }^{1,2}$, Ana Catarina Durán Bustamante ${ }^{1,2}$, Aurea Lucia Grippa de Souza ${ }^{1,2}$, Carmen Zampirole Brandão ${ }^{1,2}$, Luan Rodrigues Abdallah' ${ }^{1,2}$, Yves Pacheco Dias March e Souza ${ }^{1,2}$, Evandro Tinoco Mesquita ${ }^{1,2}$

${ }^{1}$ Fluminense Federal University, Rio de Janeiro, RJ, Brazil. ${ }^{2}$ Antônio Pedro University Hospital, Rio de Janeiro, RJ, Brazil.

\begin{abstract}
Background: Non-compacted cardiomyopathy (NCCM) is characterized by hypertrabeculations and deep recesses in the left ventricle, with a heterogeneous clinical presentation, ranging from asymptomatic patients to those with heart failure (HF), thromboembolic events and arrhythmias with risk of sudden death. As it is rare and does not have well-defined diagnostic criteria, its natural history in pediatrics is poorly understood. This study describes the clinical presentation and clinical course of patients with NCCM.
\end{abstract}

Methodology: Observational, longitudinal, prospective study of pediatric patients seen at a pediatric cardiology referral center from metropolitan region II in the state of Rio de Janeiro, with NCCM phenotype on echocardiogram (ECHO) during a 2-year follow-up, from the ChARisMa registry.

Results: 6 patients aged 4 to 14, with NCCM, were analyzed. Mean age 7.5 years (SD: 3.93), 3 males (50\%). The patients presented HF $(n=2)$, cardiac murmur $(n=1)$, cardiac arrhythmia $(n=1)$, were asymptomatic $(n=1)$ or were under investigation for a genetic syndrome $(n=1)$. Phenotypes on ECHO: NCCM/dilated cardiomyopathy $(n=1)$ and NCCM/restrictive cardiomyopathy $(n=1)$, isolated phenotype of $\operatorname{NCCM}(n=4)$. Cardiac magnetic resonance imaging was performed and confirmed the diagnosis $(n=4)$. The outcomes observed were thromboembolism, indication for heart transplantation, and sustained ventricular tachycardia.

Conclusions: This case series provides relevant data for pediatric NCCM as it shows its heterogeneous clinical presentation and potentially fatal complications. More prospective studies are needed for an accurate diagnosis and to allow its clinical course, therapeutic response and prognosis to be better known.

Keywords: Cardiomyopathy; Heart failure; Children; Pediatrics.

\section{Resumo}

Fundamentos: Miocardiopatia não compactada (MCNC) caracteriza-se por hipertrabeculações e recessos profundos no ventrículo esquerdo, com apresentação clínica heterogênea, desde pacientes assintomáticos a insuficiência cardíaca (IC), eventos tromboembólicos arritmias com risco de morte súbita. Por ser rara e não apresentar critérios diagnósticos bem definidos, sua história natural na pediatria é pouco conhecida. Este estudo descreve a apresentação e evolução clínica de pacientes portadores de MCNC.

Metodologia: Estudo observacional, longitudinal, prospectivo, de pacientes pediátricos atendidos em um centro de referência em cardiologia pediátrica provenientes da região metropolitana Il do Estado do Rio de Janeiro, com fenótipo de MCNC ao ecocardiograma (ECO) no período de 2 anos de acompanhamento, provenientes do Registro ChARisMa.

Resultados: Analisados seis pacientes com MCNC, de 4 a 14 anos de idade, média de idade de 7,5 anos (DP: 3,93), 3 do sexo masculino (50\%). Apresentando-se com IC $(n=2)$, sopro cardíaco $(n=1)$, arritmia cardíaca $(n=1)$, assintomático $(n=1)$ ou em investigação de síndrome genética $(n=1)$. Fenótipos ao ECO: MCNC/Miocardiopatia dilatada $(n=1)$ e MCNC/Miocardiopatia restritiva $(n=1)$, fenótipo isolado de MCNC ( $n=4)$. A ressonância magnética cardíaca foi realizada, confirmando o diagnóstico $(n=4)$. Os desfechos observados foram tromboembolismo, indicação de transplante cardíaco e taquicardia ventricular sustentada.

Mailing Address: Ana Flávia Malheiros Torbey•

Departamento Materno Infantil, Hospital Universitário Antônio Pedro, Universidade Federal Fluminense - Rua Marques do Paraná, 303 - Centro

CEP: 24033-900 - Niterói, RJ, Brazil

E-mail: anatorbey@id.uff.br

Manuscript received 7/25/2021; revised 10/22/2021; accepted 11/4/2021

DOI: 10.47593/2675-312X/20213404eabc237 
Conclusões: Esta série de casos proporciona dados relevantes da MCNC pediátrica, mostrando a heterogeneidade da apresentação clínica, bem como a ocorrência de complicações potencialmente fatais. São necessários mais estudos prospectivos para que seu diagnóstico seja corretamente realizado e sua evolução clínica, resposta terapêutica e prognóstico sejam mais bem conhecidos.

Palavras-chave: Cardiomiopatias; Insuficiência cardíaca; Criança; Pediatria.

\section{Introduction}

Cardiomyopathies are a group of rare diseases in childhood that, once diagnosed, are associated with high morbidity and mortality rates ${ }^{1}$. With an estimated incidence of 0.12 per 100,000 children under ten years of age, non-compaction cardiomyopathy (NCM) is the third most common pediatric CM, followed by dilated CM (DCM) and hypertrophic $\mathrm{CM}(\mathrm{HCM})^{2,3,4}$.

Also called left ventricular (LV) non-compaction, NCM was first described in 1932 in a necropsy study of a newborn. In 1986, the first echocardiographic report characterized it as spongy myocardium, and only in 2006 was it classified as a primary genetic CM by the American Heart Association (AHA). However, it remains a familial CM not classified by the European Society of Cardiology (ESC) $)^{2,5-8}$. NCM is morphologically characterized by a myocardium with trabeculations and deep recesses that communicate with the ventricular cavity. It occurs more frequently in the LV but can affect the right ventricle and the interventricular septum as an isolated or mixed phenotype (association with other cardiomyopathies, congenital heart disease, and neuromuscular diseases) ${ }^{1-3,9,10}$. Its pathophysiology is still not completely understood, but an embryogenetic failure in the myocardial layer compaction leads to hypertrabeculation and the characteristic spongy appearance. Different genetic changes controlling the sarcomeric, cytoskeletal, and mitochondrial functions have been described in NCM patients ${ }^{1-3}$.

NCM can occur at any age, with a very heterogeneous clinical presentation ranging from asymptomatic patients to heart failure (HF), thromboembolic events, arrhythmias, and sudden death ${ }^{2,6,9}$. Different echocardiographic and magnetic resonance diagnostic criteria have been proposed by different authors, hindering an accurate diagnosis ${ }^{2,8,10}$.

Given its rarity, heterogeneous etiology and clinical presentation, and absence of universal diagnostic criteria, NCM is not well known by pediatricians and causes a diagnostic challenge for pediatric cardiologists and echocardiographers. This study aims to describe the clinicodemographic characteristics and presentation phenotype of pediatric NCM patients treated at a reference center in pediatric cardiology.

\section{Methods}

This was an observational longitudinal prospective study of pediatric patients seen at a pediatric cardiology referral center with NCM phenotype on echocardiography (ECHO). These patients were part of the ChARisMA Study (Children and Adolescent Registry in Myocardites and CArdiomyopathy), which consists of a registry of patients with different myocarditis and CM phenotypes diagnosed before the age of 19 years from the Metropolitan Region II of the State of Rio de Janeiro, which covers seven municipalities: Itaboraí, Maricá, Niterói, Rio Bonito, São Gonçalo, Silva Jardim, and Tanguá.

The echocardiographic criterion for diagnosing the patients was the one described by Jenni, including a compaction-noncompaction layer ratio $>2$ measured at the end of systole, with color Doppler showing the presence of blood filling from the ventricular cavity in the deep recesses, presence of several trabeculations, and absence of structural cardiac malformations ${ }^{11}$. All ECHO images were reviewed by a second experienced examiner. Cardiac magnetic resonance imaging (CMRI) was used to confirm the echocardiographic diagnosis of NCM.

The patients underwent the most recent $\mathrm{CM}$ classification endorsed by the World Heart Federation, the MOGE(S) classification, which stands for Morphofunctional, Organ involvement, Genetic or familial, Etiology, and Stage, and was developed to describe the multiple characteristics of cardiomyopathies ${ }^{12}$. The variables studied were age at diagnosis, sex, phenotype on ECHO, clinical presentation, and family history. The outcomes analyzed were development of thromboembolic events, arrhythmias, HF development or worsening, heart transplantation, and death.

This study was approved by the local REC (CAAE: 93874218.2.0000.5243), and guardians and participants signed an informed consent and assent form as described in resolution 466/2012.

\section{Results}

From March 2019 to September 2021, 32 patients were included in the ChARisMA registry, six of whom had an echocardiographic diagnosis of NCM, representing 18.75\% of the cases. These patients are still being followed up.

Of the six NCM patients, three were male (50\%) and three were female. The age at diagnosis was 4-14 years (mean, 7.5 years; median, 7 ; and standard deviation, 3.93). At the time of diagnosis, two patients had $\mathrm{HF}$, both with a mixed phenotype on ECHO, one with NCM and DCM, and the other with NCM and restrictive $\mathrm{CM}(\mathrm{RCM})$. The other cases $(\mathrm{n}=4)$ presented an isolated NCM phenotype on ECHO (Figure 1). The main characteristics of this case series are shown in Table 1.

All patients underwent the $\operatorname{MOGE}(\mathrm{S})$ classification (Table 2), which describes the phenotype, family history, etiology, and clinical condition of the patient by HF functional class and staging.

Diagnosis was based on HF symptoms ( $\mathrm{n}=2)$ and physical examination changes such as heart murmur and cardiac arrhythmia - ventricular extrasystole $(n=2)$, one patient underwent familial screening with the phenotype confirmed on $\mathrm{ECHO}$, and the other was confirmed in the context of the possible associated malformations on genetic syndrome investigation. $\mathrm{CMRI}$ performed in four cases confirmed the $\mathrm{ECHO}$ diagnosis. 


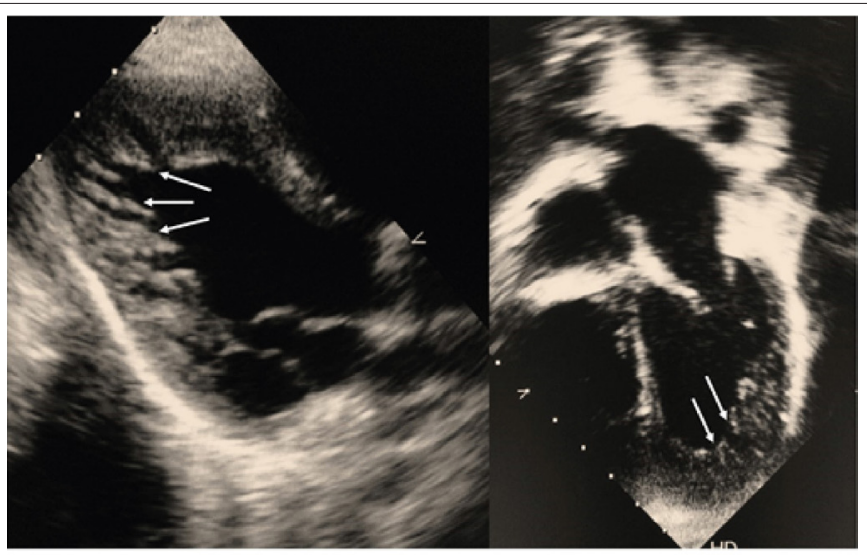

Figure 1 - Two-dimensional echocardiogram of a patient with non-compaction cardiomyopathy. The arrows show the non-compaction layer with excess trabeculations and the characteristic deep recesses at the left ventricular apex and free wall.

Table 1 - Clinical characteristics and progression of NCM patients.

\begin{tabular}{|c|c|c|c|c|c|c|c|c|c|}
\hline ID & Sex & $\begin{array}{c}\text { Age at } \\
\text { diagnosis } \\
\text { (years) }\end{array}$ & $\begin{array}{l}\text { Reason for } \\
\text { diagnosis }\end{array}$ & $\begin{array}{l}\text { Functional } \\
\text { class } \\
\text { (NYHA) }\end{array}$ & $\begin{array}{l}\text { Phenotype } \\
\text { on ECHO }\end{array}$ & $\begin{array}{l}\text { 24-hour } \\
\text { Holter }\end{array}$ & CMRI & $\begin{array}{l}\text { Observations } \\
\text { throughout follow-up }\end{array}$ & $\begin{array}{l}\text { Patient condition at the end of } \\
\text { follow-up }\end{array}$ \\
\hline 1 & M & 5 & $\begin{array}{l}\text { Heart murmur } \\
\text { to be clarified }\end{array}$ & 1 & $\mathrm{NCM}$ & No changes & Yes & Absent & $\begin{array}{l}\text { Asymptomatic, functional class I } \\
\text { (NYHA) }\end{array}$ \\
\hline 2 & M & 9 & $\begin{array}{l}\text { Family screening } \\
\text { (case 1's brother) }\end{array}$ & I & $\mathrm{NCM}$ & -- & No & Absent & $\begin{array}{l}\text { Asymptomatic, functional class I } \\
\text { (NYHA) }\end{array}$ \\
\hline 3 & $F$ & 9 & $\begin{array}{l}\text { Heart } \\
\text { failure }\end{array}$ & III & $\mathrm{NCM} / \mathrm{RCM}$ & $\begin{array}{l}\text { NSSVT } \\
\text { NSVT }\end{array}$ & Yes & $\begin{array}{l}\text { Pulmonary } \\
\text { thromboembolism, } \\
\text { functional class IV } \\
\text { (NYHA), included in the } \\
\text { heart transplant list }\end{array}$ & Death \\
\hline 4 & $F$ & 14 & Heart failure & II & $\mathrm{NCM} / \mathrm{RCM}$ & $\begin{array}{l}\text { Without } \\
\text { changes }\end{array}$ & No & Absent & $\begin{array}{l}\text { Functional class II (NYHA), } \\
\text { medicated with carvedilol }\end{array}$ \\
\hline 5 & $\mathrm{~F}$ & 4 & $\begin{array}{l}\text { Irregular rhythm } \\
\text { (ventricular } \\
\text { extrasystole on } \\
\text { ECG) }\end{array}$ & 1 & $\mathrm{NCM}$ & VT & Yes & $\begin{array}{l}\text { Sustained ventricular } \\
\text { tachycardia }\end{array}$ & $\begin{array}{l}\text { Controlled arrhythmia after ablation } \\
\text { and use of amiodarone. }\end{array}$ \\
\hline 6 & M & 4 & $\begin{array}{l}\text { Screening for } \\
\text { malformations } \\
\text { associated with } \\
\text { genetic syndrome } \\
\text { to be clarified }\end{array}$ & 1 & $\mathrm{NCM}$ & $\begin{array}{l}\text { Without } \\
\text { changes }\end{array}$ & Yes & $\begin{array}{l}\text { Genetic diagnosis of } \\
22 q 13 \text { microdeletion } \\
\text { confirmed (Phelan- } \\
\text { McDermid Syndrome) }\end{array}$ & $\begin{array}{l}\text { Functional class I (NYHA), hypotonia, } \\
\text { global developmental delay }\end{array}$ \\
\hline
\end{tabular}

CMRI, cardiac magnetic resonance imaging; ECG, electrocardiogram; ECHO, echocardiogram; F, feminine; ID, identification; M, male; NSSVT, non-sustained supraventricular tachycardia; NSVT, non-sustained ventricular tachycardia; NYHA, New York Heart Association; VT, sustained ventricular tachycardia.

The outcomes included arrhythmia on 24-hour Holter monitoring: non-sustained supraventricular tachycardia and non-sustained ventricular tachycardia and sustained ventricular tachycardia (Figure 2). In addition to pulmonary thromboembolism (PTE) in the case of a mixed NCM/RCM phenotype that progressed with HF worsening, the patient died after a 27-month follow-up despite drug optimization and referral for heart transplantation.

\section{Discussion}

As a rare disease, little is known about the clinical progression, prognosis, and treatment of pediatric $\mathrm{NCM}^{2,3}$. Its classification as a distinct $\mathrm{CM}$ remains controversial, being defined as genetic primary CM by the AHA in 2006 but still
Table 2 - The MOGES classification (Morphofunctional, Organ involvement, Genetic or familial, Etiology, Stage).

\begin{tabular}{|c|c|}
\hline Id & MOGES \\
\hline 1 & $\mathrm{M}_{\mathrm{NC}} \mathrm{O}_{\mathrm{H}} \mathrm{G}_{\text {Undet }} \mathrm{E}_{0} \mathrm{~S}_{\mathrm{B}-\mathrm{I}}$ \\
\hline 2 & $\mathrm{M}_{\mathrm{NC}} \mathrm{O}_{\mathrm{H}} \mathrm{G}_{\text {Undet }} \mathrm{E}_{0} \mathrm{~S}_{\mathrm{B}-\mathrm{I}}$ \\
\hline 3 & $M_{R+N C} O_{H+C+L U} G_{U} E_{0} S_{D-N V}$ \\
\hline 4 & $\mathrm{M}_{\mathrm{D}+\mathrm{NC}} \mathrm{O}_{\mathrm{H}} \mathrm{G}_{\mathrm{N}} \mathrm{E}_{0} \mathrm{~S}_{\mathrm{C}-\|}$ \\
\hline 5 & $\mathrm{M}_{\mathrm{NC}} \mathrm{O}_{\mathrm{H}} \mathrm{G}_{\mathrm{N}} \mathrm{E}_{0} \mathrm{~S}_{\mathrm{B}-1}$ \\
\hline 6 & $\mathrm{M}_{\mathrm{NC}} \mathrm{O}_{\mathrm{H+N+ \textrm {K }}} \mathrm{G}_{22013 \text { deletion }} \mathrm{E}_{G} \mathrm{~S}_{\mathrm{B}}-$, \\
\hline
\end{tabular}

$E_{0}$, without genetic testing; $G_{N}$, negative family history; $G_{\text {under }}$ genetic heritage undetermined; ID, patient identification; $M$ c, non-compaction cardiomyopathy; $M_{R N C}$, restrictive and non-compaction cardiomyopathy; $\mathrm{O}_{H}$, heart involvement; $\mathrm{O}_{H+C+w^{\prime}}$ heart, skin, and lung involvement; $\mathrm{O}_{H+N+K^{\prime}}$ heart, neurological, and kidney involvement; S, New York Heart Association functional classification (I-IV) and American College of Cardiology/American Heart Association staging $(A-D)$. 


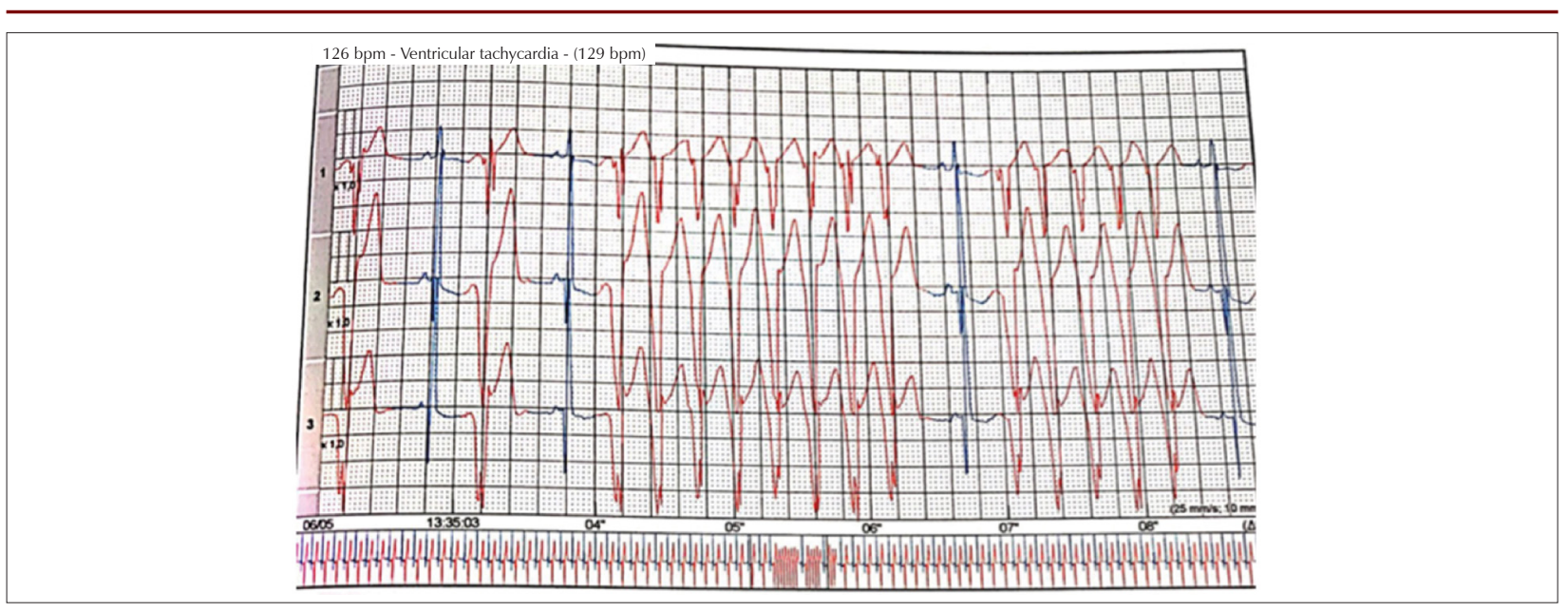

Figure 2 - A 24-hour Holter monitor tracing showing sustained ventricular tachycardia in a patient with non-compaction cardiomyopathy.

being a non-classified $\mathrm{CM}$ by the $\mathrm{ESC}^{2,6,7,13}$. More recently, the $\operatorname{MOGE}(\mathrm{S})$ classification was developed from the need to describe $\mathrm{CM}$ integrating multiple characteristics of the disease. In addition to the morphofunctional phenotype $(M)$, it considers organ involvement $(\mathrm{O})$, family inheritance pattern or genetic basis (G) and etiology (E) (genetic or acquired), and functional status (S) based on the ACC/AHA HF staging (A-D) and the New York Heart Association functional class (I-IV) 1,12

Both main pediatric $\mathrm{CM}$ registries, the Australian one (1987-1996) and the Pediatric Cardiomyopathies Registry that included 98 centers in the United States and Canada (1990-2008), report an NCM incidence of $9.2 \%$ and $4.8 \%$ of all CM cases diagnosed in childhood, respectively,14. To date, the literature has no pediatric records on this CM in Latin America, only isolated case reports. Therefore, this case series presents important pediatric NCM data in this environment.

Corroborating the literature, the case series studied shows pediatric NCM heterogeneity from clinical presentation to diagnosis ranging from asymptomatic patients to ventricular arrhythmia and HF or in the context of genetic syndrome investigation ${ }^{1,3,4,13-15}$.

$\mathrm{HF}$ is the most common clinical presentation of $\mathrm{NCM}^{1-4}$, $14,16,17$, so the recognition of the several HF signs and symptoms in children essential to its diagnosis ${ }^{18}$. HF was also the main clinical presentation in the described group of patients.

The diagnosis in asymptomatic patients remains debatable since the presence of hypertrabeculation in the absence of ventricular dysfunction could be considered only a morphological characteristic as described in high-performance athletes, pregnant women, and black people $e^{1,19,20}$. There is still no available imaging method, genetic test, or histopathological evaluation for the differential diagnosis of NCM and the presence of physiological hypertrabeculation. In the present study, $50 \%$ of the cases presented no cardiovascular symptoms, but the fact that two patients had a positive family history and one had a confirmed genetic disease diagnosis suggests that the NCM phenotype is not just a physiological hypertrabeculation. Therefore, the long-term follow-up of this group of patients with future assessments and family screening is essential ${ }^{2,16,20}$.

Doppler ECHO is the main method for NCM diagnosis, which is characterized by a myocardium with two layers, one external and compact and the other internal and noncompact, thick and with trabeculations and deep recesses that communicate with the ventricular cavity and are often located in the LV apex and free wall ${ }^{2,19,21}$.

Accurate imaging diagnosis can be quite difficult due to the overlap with other CM types such as DCM and even the presence of normal LV trabeculations ${ }^{21,22}$. In a prospective study, Lilje et al. reported that NCM can be underdiagnosed. Jurko et al. consider that the main reason for the late diagnosis is the lack of physicians' experience recognizing $\mathrm{NCM}^{16,21}$.

Several authors proposed different diagnostic criteria using two-dimensional ECHO (Jenni et al., Chin et al., Stöllberger

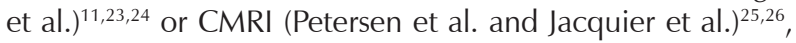
which prevents a universal consensus for diagnosis. In addition, healthy people may present with increased trabeculations and meet these criteria, which makes it necessary to clarify whether asymptomatic patients are in a preclinical phase of CM or just show a variation of normality ${ }^{2,19,27}$.

These criteria are based on the relationship between the compaction and non-compaction layers; however, they differ regarding the time of the cardiac cycle in which the measurement must be performed ${ }^{8}$. The criterion proposed by Jenni ${ }^{11}$ consists of a ratio greater than two at the end of systole, being the most frequently used in studies available in the literature ${ }^{2,28,29}$. Neme et al. highlights the importance of techniques such as real-time 3D ECHO and speckle tracking in understanding this $\mathrm{CM}^{30}$. CMRI contributes to the diagnosis, especially when the $\mathrm{ECHO}$ is uncertain and the ratio between the compaction and non-compaction layers greater than 2.3 has a sensitivity of $86 \%$ and a specificity of $99 \%$ (Petersen criterion $)^{2,21}$. In addition to confirming the diagnosis, imaging studies are essential for phenotype categorization (mixed or isolated) and the determination of systolic and diastolic function, providing the physician with necessary information on its clinical progression and treatment ${ }^{31}$. 
In the present case series, two patients could not undergo CMRI, and only the Jenni's ECHO criterion was used ${ }^{11}$ associated with the family history and clinical presentation. These patients had a positive family history or HF signs and symptoms, and hypertrabeculation was characterized as NCM, not just as a physiological condition. As imaging methods do not determine the NCM pathognomonic sign, the Rotterdam criteria were proposed to differentiate pathological NCM trabeculations from the physiological trabeculations found in athletes, Afrodescendants, and long-term hypertensive patients. This criterion consists of clinical evaluation combined with ECG, ECHO/ CMRI, family history, and genetic evaluation ${ }^{2}$.

The most frequent NCM phenotype in children is the nonisolated form, which presents concomitantly with other $\mathrm{CM}$ or congenital heart disease (mixed phenotype) or associated with genetic syndrome, neuromuscular disease, or inborn error of metabolism ${ }^{2,3}$. The North American and Australian registries showed that the most common phenotype was mixed, with NCM/DCM of $58.7-93 \%$, followed by NCM/HCM (11\%). The association with $\mathrm{RCM}$ is very rare ${ }^{4,14}$. An anatomopathological study by Marques et al. ${ }^{10}$ showed that ventricular septal defect is the congenital heart disease most commonly associated with NCM. On the other hand, this case series presented a predominance of the isolated form, corroborating the study by Jurko et al. ${ }^{21}$.

No specific drug or surgical therapy strategy has been successfully introduced for NCM. However, the use of a betablocker or an angiotensin-converting enzyme inhibitor can lead to favorable LV remodeling 2,16,20. A case report by Redondo et al. described an important improvement in refractory HF after use of the phosphodiesterase-5 inhibitor (sildenafil) in a six-year-old boy ${ }^{32}$. Patients with a mixed phenotype or associated systemic condition should undergo targeted therapy ${ }^{3,13,28,33}$.

Once NCM is diagnosed, patients should be closely monitored for possible complications and ventricular function deterioration. Imaging tests such as ECHO and CMRI, ECG, 24-hour Holter monitoring, and exercise stress testing should be performed whenever possible to rule out exercise-induced arrhythmia ${ }^{2,3}$. Arrhythmias should be treated according to the established clinical protocols ${ }^{2}$. One of the cases presented here progressed with sustained ventricular tachycardia for which the patient underwent ablation and remains free from new episodes of arrhythmia during the follow-up period.

Effort is needed to determine whether anticoagulation or prophylactic antiplatelet therapy is justified and beneficial in children $^{2,3}$. If cardiac function deteriorates despite optimized drug therapy, the viable option is heart transplantation. In North America, 4\% of pediatric patients listed for heart transplantation are diagnosed with isolated $\mathrm{NCM}^{2}$.

A study by Lofiego et al. of a cohort of adult patients demonstrated that disease presentation at diagnosis can determine the prognosis ${ }^{34}$. Asymptomatic patients have a better prognosis than those with HF or VT, even children with an isolated NCM phenotype have better clinical progression ${ }^{1,3,13,14,16}$. This also occurred in this case series, in which patients with mixed phenotypes (NCM/DCM and $\mathrm{NCM} / \mathrm{RCM}$ ) still required $\mathrm{HF}$ treatment in addition to presenting complications such as PTE, indication for heart transplantation, and death.

In the study by BRESCIA et al. ${ }^{16}$, being less than 12 months of age at diagnosis, LV systolic dysfunction, and ventricular arrhythmia were considered risk factors for death or heart transplantation. A systematic review by van Waning et al. ${ }^{35}$ reported that children have a more severe presentation than adults.

Childhood cardiomyopathies have an important and heterogeneous genetic substrate in their etiology derived from multiple mutations in several genes. Variants in the same gene can cause different phenotypes and systemic changes that commonly affect organs other than the heart. More than 40 monogenetic and chromosomal defects have been described in the NCM population, with different inheritance patterns (autosomal dominant, autosomal recessive, and X-linked). NCM is a common finding in Barth syndrome, an autosomal recessive $X$-linked disease with mutation in the tafazzin (TAZ) gene on chromosome $\mathrm{Xq} 28$; it is also found in inborn errors of metabolism such as glycogen storage disease type 1, decarboxylase deficiency, and cobalamin C deficiency and associated with aneuploidies (Turner syndrome or trisomy 13,18 , and 21$)$, copy number variations (22q11 and 1 p36 deletion), neuromuscular disease (Duchenne and Becker dystrophy), mitochondrial diseases, and other genetic syndromes (Soto, Marfan, and RASopathies) 2,3,28.

Due to the genetic characteristic of NCM, family screening must always be performed using $\mathrm{ECHO}$, with a possible early phenotypic diagnosis in asymptomatic patients. About $25-50 \%$ of patients with NCM have a positive family history ${ }^{2,14,15,28,29,35,36}$. Genetic studies should also be encouraged despite the difficult access and numerous ethical issues involved in the genetic diagnosis of asymptomatic patients ${ }^{2}$. According to a study published by van Waning, genetic causes have a worse prognosis in pediatric than adult patients, and NCM more commonly has a genetic cause when diagnosed in children, especially those younger than one year of age ${ }^{37}$. Although genetic investigations were not conducted in all cases analyzed, family screening identified one case of NCM (brother) and one of a 22q11 microdeletion.

The use of the MOGE(S) classification in the studied cases proved useful in gathering fundamental characteristics requiring addressing in patients with cardiomyopathies, such as a morphofunctional phenotype, involvement of other organs and systems, family history, genetic changes, and clinical status through HF functional and staging classification, providing better understanding of the disease $e^{1,12,38,39}$.

\section{Conclusions}

This case series provides relevant data on pediatric NCM, showing heterogeneous clinical presentation and the occurrence of potentially fatal complications. A limiting factor of the study is its small number of patients. More prospective studies are needed to ensure that NCM is correctly diagnosed and its clinical progression, therapeutic response, and prognosis are better known.

\section{Authors' contributions}

Research conception and design, critical review of the manuscript for important intellectual content: Torbey AFM, Souza ALAAG, Mosque ET; Data collection: Torbey AFM, 
Souza ALAAG, Bustamante ACD, Brandão CZ, Abdallah LR, Souza YPDM; Manuscript writing: Torbey AFM, Souza ALAAG, Bustamante ACD, Brandão CZ, Abdallah LR, Souza YPDM, Mesquita ET.

This article is part of the Phd thesis by Ana Flávia Malheiros Torbey and Aurea Lúcia Alves de Azevedo Grippa

\section{References}

1. Lipshultz SE, Law YM, Asante-Korang A, Austin ED, Dipchand AI, Everitt MD, et al. Cardiomyopathy in children: classification and diagnosis: a scientific statement from the American Heart Association. Circulation. 2019;140(1):e9-e68. doi: https://doi.org/10.1161/ CIR.0000000000000682

2. Rohde S, Muslem R, Kaya E, Dalinghaus M, van Waning JI, Majoor-Krakauer $D$, et al. State-of-the art review: Noncompaction cardiomyopathy in pediatric patients. Heart Fail Rev. 2021.doi: https://doi.org/10.1007/ s10741-021-10089-7

3. Lee TM, Hsu DT, Kantor P, Towbin JA, Ware SM, Colan SD, et al. Pediatric Cardiomyopathies. Circ Res. 2017;121(7):855-73. doi: 10.1161/ CIRCRESAHA. 116.309386

4. Shi WY, Moreno-Betancur M, Nugent AW, Cheung M, Colan S, Turner C, et al.; National Australian Childhood Cardiomyopathy Study. Long-Term Outcomes of Childhood Left Ventricular Noncompaction Cardiomyopathy: Results From a National Population-Based Study. Circulation. 2018;138(4):367-76. doi: 10.1161/CIRCULATIONAHA.117.032262

5. Engberding R, Bender F. Identification of a rare congenital anomaly of the myocardium by two-dimensional echocardiography: persistence of isolated myocardial sinusoids. Am J Cardiol. 1984;53(11):1733-4. doi: 10.1016/0002-9149(84)90618-0

6. Maron BJ, Towbin JA, Thiene G, Antzelevitch C, Corrado D, Arnett D, et al.; American Heart Association; Council on Clinical Cardiology, Heart Failure and Transplantation Committee; Quality of Care and Outcomes Research and Functional Genomics and Translational Biology Interdisciplinary Working Groups; Council on Epidemiology and Prevention. Contemporary definitions and classification of the cardiomyopathies: an American Heart Association Scientific Statement from the Council on Clinical Cardiology, Heart Failure and Transplantation Committee; Quality of Care and Outcomes Research and Functional Genomics and Translational Biology Interdisciplinary Working Groups; and Council on Epidemiology and Prevention. Circulation. 2006;113(14):1807-16. doi: 10.1161/ CIRCULATIONAHA.106.174287

7. Elliott P, Andersson B, Arbustini E, Bilinska Z, Cecchi F, Charron P, et al. Classification of the cardiomyopathies: a position statement from the European Society Of Cardiology Working Group on Myocardial and Pericardial Diseases. Eur Heart J. 2008;29(2):270-6. doi: 10.1093/eurheartj/ehm342

8. Hotta VT, Tendolo SC, Rodrigues AC, Fernandes F, Nastari L, Mady C. Limitations in the diagnosis of noncompaction cardiomyopathy by echocardiography. Arq Bras Cardiol. 2017;109(5):483-8.

9. Hirono K, Hata Y, Miyao N, Okabe M, Takarada S, Nakaoka H, et al.; Lvnc Study Collaborators. Left Ventricular Noncompaction and Congenital Heart Disease Increases the Risk of Congestive Heart Failure. J Clin Med. 2020;9(3):785. doi: 10.3390/jcm9030785

10. Marques LC, Liguori GR, Amarante Souza AC, Aiello VD. Left ventricular noncompaction is more prevalent in ventricular septal defect than other congenital heart defects: a morphological study. J Cardiovasc Dev Dis. 2020;7(4):39. doi: 10.3390/jcdd7040039

11. Jenni R, Oechslin E, Schneider J, Attenhofer Jost C, Kaufmann PA. Echocardiographic and pathoanatomical characteristics of isolated left ventricular non-compaction: a step towards classification as a distinct cardiomyopathy. Heart. 2001;86(6):666-71. doi: 10.1136/ heart.86.6.666 de Souza, from the Graduate Program in Sciences Program Cardiovascular at the Fluminense Federal University.

\section{Conflict of interest}

The authors have declared that they have no conflict of interest.

12. Arbustini E, Narula N, Dec GW, Reddy KS, Greenberg B, Kushwaha S, et al. The MOGE(S) classification for a phenotype-genotype nomenclature of cardiomyopathy: endorsed by the World Heart Federation. J Am Coll Cardiol. 2013;62(22):2046-72. doi: 10.1016/j.jacc.2013.08.1644. Erratum in: J Am Coll Cardiol. 2014;63(2):191-4.

13. De Angelis G, Bobbo M, Paldino A, D'Agata Mottolese B, Altinier A, Dal Ferro $M$, et al. Cardiomyopathies in children: classification, diagnosis and treatment. Curr Opin Organ Transplant. 2020;25(3):218-30. doi: 10.1097/ MOT.0000000000000755

14. Jefferies JL, Wilkinson JD, Sleeper LA, Colan SD, Lu M, Pahl E, et al.; Pediatric Cardiomyopathy Registry Investigators. Cardiomyopathy phenotypes and outcomes for children with left ventricular myocardial noncompaction: results from the pediatric cardiomyopathy registry. J Card Fail. 2015;21(11):877-84. doi: 10.1016/j.cardfail.2015.06.381

15. Sousa O, Silva G, Sampaio F, Oliveira M, Gonçalves H, Primo J, et al. [Isolated left ventricular non-compaction: a single-center experience]. Rev Port Cardiol. 2013;32(3):229-38. Portuguese.

16. Brescia ST, Rossano JW, Pignatelli R, Jefferies JL, Price JF, Decker JA, et al. Mortality and sudden death in pediatric left ventricular noncompaction in a tertiary referral center. Circulation. 2013;127(22):2202-8. doi: 10.1161/ CIRCULATIONAHA.113.002511

17. Lilje C, Rázek V, Joyce JJ, Rau T, Finckh BF, Weiss F, et al. Complications of non-compaction of the left ventricular myocardium in a paediatric population: a prospective study. Eur Heart J. 2006;27(15):1855-60. doi: 10.1093/eurheartj/ehl112

18. Capin I, Capone CA, Taylor MD. Acute on Chronic Heart Failure Secondary to Left Ventricular Noncompaction. Case Rep Pediatr. 2020;2020:6369806. doi: 10.1155/2020/6369806

19. Melo MD, Salemi VM. Noncompaction cardiomyopathy - is it a new "prolapse"? an early stigma of cardiomyopathy. Arq Bras Cardiol: Imagem Cardiovasc. 2020;33(2):e000PB85. doi: DOI: 10.5935/2318-8219.20200019

20. Oechslin E, Jenni R. Left ventricular non-compaction revisited: a distinct phenotype with genetic heterogeneity? Eur HeartJ. 2011;32(12):1446-56. doi: 10.1093/eurheartj/ehq508

21. Jurko T, Jurko A Jr, Mistinova Polakova J, Jurko A, Minarik M, Mestanik M, et al. Risk of delayed diagnosis in young patients with left ventricular noncompaction - a potential benefit of magnetic resonance imaging. Neuro Endocrinol Lett. 2019;40(2):68-74. PMID: 31785212.

22. Patel AR, Kramer CM. Role of Cardiac Magnetic Resonance in the Diagnosis and Prognosis of Nonischemic Cardiomyopathy. JACC Cardiovasc Imaging. 2017;10(10 PtA):1180-1193. doi: 10.1016/j.jcmg.2017.08.005

23. Chin TK, Perloff JK, Williams RG, Jue K, Mohrmann R. Isolated noncompaction of left ventricular myocardium. A study of eight cases. Circulation. 1990;82(2):507-13. doi: 10.1161/01.cir.82.2.507

24. Stöllberger C, Gerecke B, Finsterer J, Engberding R. Refinement of echocardiographic criteria for left ventricular noncompaction. Int J Cardiol. 2013;165(3):463-7. doi: 10.1016/j.ijcard.2011.08.845

25. Petersen SE, Selvanayagam JB, Wiesmann F, Robson MD, Francis $J \mathrm{M}$, Anderson $\mathrm{RH}$, et al. Left ventricular non-compaction: insights from cardiovascular magnetic resonance imaging. J Am Coll Cardiol. 2005;46(1):101-5. doi: 10.1016/j.jacc.2005.03.045 
26. Jacquier A, Thuny F, Jop B, Giorgi R, Cohen F, GaubertJY, et al. Measurement of trabeculated left ventricular mass using cardiac magnetic resonance imaging in the diagnosis of left ventricular non-compaction. Eur Heart J. 2010;31(9):1098-104. doi: 10.1093/eurheartj/ehp595

27. Garcia-Pavia P, de la Pompa JL. Left ventricular noncompaction: a genetic cardiomyopathy looking for diagnostic criteria. J Am Coll Cardiol. 2014;64(19):1981-3. doi: 10.1016/j.jacc.2014.08.034. Erratum in: J Am Coll Cardiol. 2015;65(5):519.

28. Arbustini E, Weidemann F, Hall JL. Left ventricular noncompaction: a distinct cardiomyopathy or a trait shared by different cardiac diseases? J Am Coll Cardiol. 2014;64(17):1840-50. doi: 10.1016/j.jacc.2014.08.030

29. Rosa LV, Salemi VM, Alexandre LM, Mady C. Noncompaction cardiomyopathy: a current view. Arq Bras Cardiol. 2011;97(1):e13-9. English, Portuguese, Spanish. doi: 10.1590/s0066-782×2011000900021

30. Nemes A, Forster T. Evaluation of noncompaction cardiomyopathy by modern echocardiographic methods. Arq Bras Cardiol. 2012;98(5):467. doi: 10.1590/s0066-782×2012000500013

31. Mejia EJ, O'Connor MJ. The role of imaging in assessing disease severity and prognosis in cardiomyopathy. Progress in Pediatric Cardiology. 2020;59:101316.

32. Redondo AC, Fuenmayor G, Shiraishi KS, Fontes SR, Elias PF, Souza R et al. Sildenafil for noncompaction cardiomyopathy treatment in a child: case report. Arq Bras Cardiol. 2014;102(3):e27-30.

33. Pignatelli RH, McMahon CJ, Dreyer WJ, Denfield SW, Price J, Belmont $\mathrm{JW}$, et al. Clinical characterization of left ventricular noncompaction in children: a relatively common form of cardiomyopathy. Circulation. 2003;108(21):2672-8. doi: 10.1161/01.CIR.0000100664.10777.B8

34. Lofiego C, Biagini E, Pasquale F, Ferlito M, Rocchi G, Perugini E, et al Wide spectrum of presentation and variable outcomes of isolated left ventricular non-compaction. Heart. 2007;93(1):65-71. doi: 10.1136/ hrt.2006.088229

35. van Waning JI, Moesker J, Heijsman D, Boersma E, Majoor-Krakauer D. Systematic review of genotype-phenotype correlations in noncompaction cardiomyopathy. J Am Heart Assoc. 2019;8(23):e012993. doi: 10.1161/ JAHA.119.012993

36. van Waning JI, Caliskan K, Michels M, Schinkel AF, Hirsch A, Dalinghaus M, et al. Cardiac Phenotypes, Genetics, and Risks in Familial Noncompaction Cardiomyopathy. J Am Coll Cardiol. 2019;73(13):1601-11. doi: 10.1016/j. jacc.2018.12.085

37. van Waning JI, Caliskan K, Hoedemaekers YM, van Spaendonck-Zwarts KY, Baas AF, Boekholdt SM, et al. Genetics, Clinical Features, and LongTerm Outcome of Noncompaction Cardiomyopathy. J Am Coll Cardiol. 2018;71(7):711-22. doi: 10.1016/j.jacc.2017.12.019

38. Sánchez MD, Castro AM, Poymiró SH. Left ventricular non-compaction cardiomyopathy: outlook and cardiac arrhythmias. Cor Salud. 2018;10(1):52-6.

39. Arbustini E, Narula N, Tavazzi L, Serio A, Grasso M, Favalli V, et al. The MOGE(S) classification of cardiomyopathy for clinicians. J Am Coll Cardiol. 2014;64(3):304-18. doi: 10.1016/j.jacc.2014.05.027. Erratum in: J Am Coll Cardiol. 2014;64(11):1186. Bonow, Robert D [Corrected to Bonow, Robert O]. 